\title{
Research Paper \\ Development of Social Relationships in Children Aged 4 to 6 in Qom Kindergartens Based on the Demographic Status of Families in 2016
}

Mahdi Ghelichi ${ }^{1}$, Hamze Ganji*2, Malek Mirhashemi ${ }^{3}$, Siyamak Tahmasebi Garmtani ${ }^{4}$

1. Ph.D. Student of Psychology, Rudehen Branch, Islamic Azad University, Rudehen, Iran

2. Professor, Department of Psychology, Rudehen Branch, Islamic Azad University, Rudehen, Iran

3. Associate Profssor, Department of Psychology, Rudehen Branch, Islamic Azad University, Rudehen, Iran

4. Assisstant Professor, Department of Preschool Education, Faculty of Educational Sciences, University of Social Walfare and

Rehabilitation Sciences, Tehran, Iran

Citation: Ghelichi M, Ganji H, Mirhashemi M, Tahmasebi Garmtani S. Development of social relationships in children aged 4 to 6 in qom kindergartens based on the demographic status of families in 2016. Quarterly Journal of Child Mental Health. 2020; 7(2): $216-228$.

http://dx.doi.org/10.29252/jcmh.7.2.19

\section{A R T I C L E I N F O}

\section{Keywords:}

Social relationships,

kindergarten,

demographic status of

families

Received: 26 Jul 2018

Accepted: 23 Sep 2019

Available: 21 Sep 2020

\section{A B S T R A C T}

Background and Purpose: Man is a social being. The social aspect of child development shapes the basis of his/her life. Social life demands mental readiness, social skills, self-confidence, and social adjustment. This study aimed to determine the development of social relationships in children aged 4 to 6 in the kindergartens of Qom province, based on the demographic status of their families.

Method: To carry out this causal-comparative study, 300 children aged 4 to 6 (150 boys and 150 girls) were selected by multi-stage cluster sampling from ten kindergartens of Qom province in 2016. Development of social relationships in these children was determined based on the subscale of the social relationship in Newsha Cognitive, Social Communication and Motor Development Scale for Persian Speaking Children (Jafari et al., 2009) and Researcher-made Demographic Test. Descriptive statistical techniques, Kruskal-Wallis test, and Mann-Whitney U- were used to analyze the data.

Results: Results showed that development of social relationships in these children improved with age. The demographic variables, including the paternal level of education ( $p<0.714)$, maternal level of education $(p<0.574)$, paternal income $(p<0.796)$, maternal income $(p<0.479)$, housing status of the family $(\mathrm{p}<0.330)$, history of parental death or divorce or death of a loved one $(\mathrm{p}<0.433)$, history of psychiatric problems in siblings $(\mathrm{p}<0.758)$, being right-handed or left- handed $(\mathrm{P}<0.351)$, being monolingual or bilingual ( $\mathrm{p}<0.907$ ) had no effect on the development of social relationships in these children.

Conclusion: In general, results of this study showed that based on developmental theories like social development theory and social learning theory, child's social relationships improves with age. Also, noneffectiveness of family demographic factors on the child's social relationships indicates the importance of social learning theory and it shows that children are affected by socialization factors outside the family. \footnotetext{
E-mail addresses: Ganji@riau.ac.ir

* Corresponding author: Hamze Ganji, Professor, Department of Psychology, Rudehen Branch, Islamic Azad University, Rudehen, Iran. 


\title{
وضعيت تحول ارتباط اجتماعى در كودكان ع تا ح سال مهد كودكىهاى استان قم بر اساس وضعيت جمعيتشناختى خانوادهها در سال
}

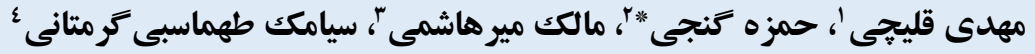

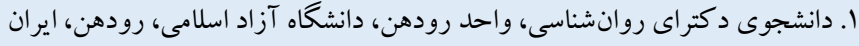

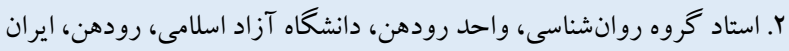

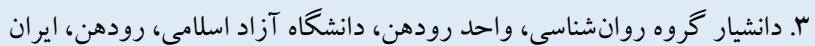

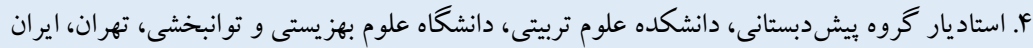
مشخصات مقاله

زمينه و هدف: انسان، موجودى اجتماعى است و جنبه اجتماعى تحول كودكى، بِايه و اساس زندگى انسانى را تشكيل مىدهد. زندگى

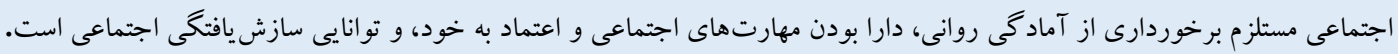

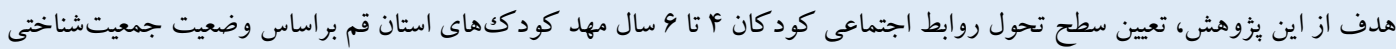
خانوادههاى آنها بود.

جكيده

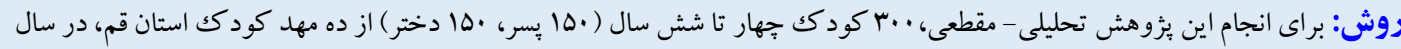

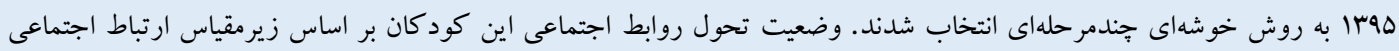
مربوط به آزمون سنجش تحول شناخت، ارتباط اجتماعى و حركت نيوشا در كود كان فارسىزبان (جعفرى و همكاران، MM IIM) و آزمون

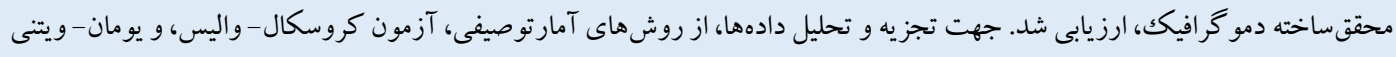
استفاده شد. يافتهها: نتايج نشان داد كه روند تحول روابط اجتماعى در اين كود كان، با افزايش سن، ييشرفت مى كند و متغيرهاى جمعيتشناختى شامل تحصيلات يدران (p|F/p)

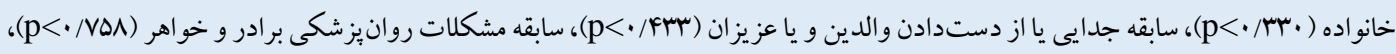

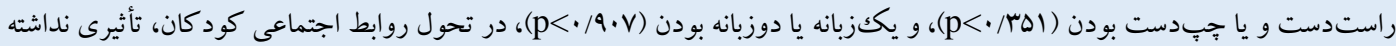

نتيجه كيرى: به طور كلى نتايج اين يزوهش نشان مىدهد كه بر اساس نظريههاى تحولى مانند نظريه تحول اجتماعى و نظريه يادگيرى اجتماعى، روابط اجتماعى كود كان همراه با افزايش سن بيشرفت مى كند. همجنين عدم تأثير متغيرهاى جمعيت شناختى خانو ادهها در روابط اجتماعى كود كان، تأيدى بر اهميت نظريه ياد گيرى اجتماعى، و نشانه اثريذيرى كود كان از عوامل اجتماعى شدن در محيط بيرون از خانواده، 
نسبت به نمره ملاكك داشت (م). نتايج يُزوهش صفرى، حسنوند، فياض،

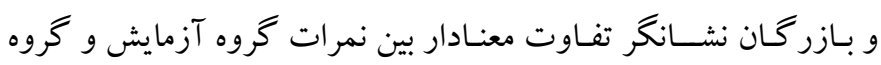

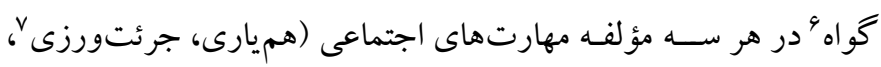

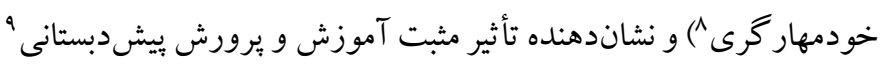

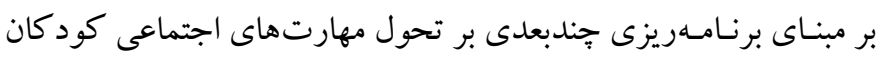

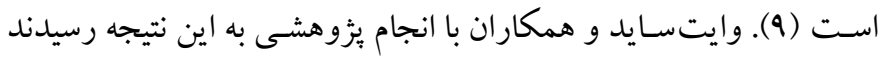
كـه با ارزيابى جنبه هاى مثبت و منفى رفتار و روابط با همســالان، امكان ونهان

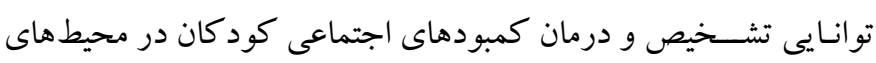

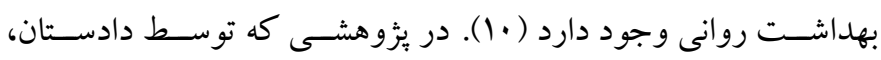

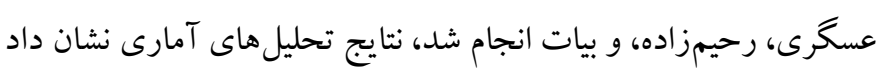

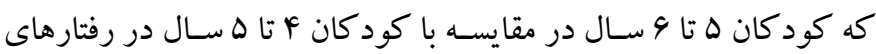

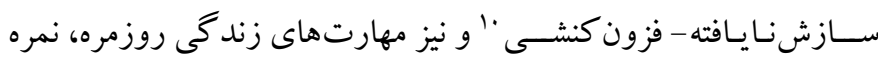

$$
\text { بيشترى به دست آوردند (11). }
$$

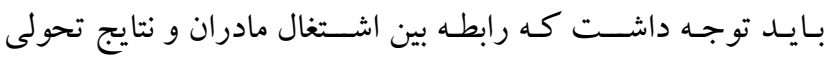
كود كان، يككبعدى نيسـت. براى مثال، كود كانى كه مادران آنها شــل

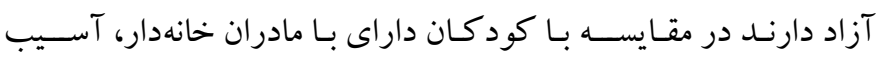

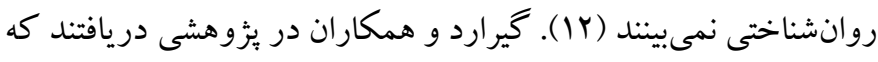

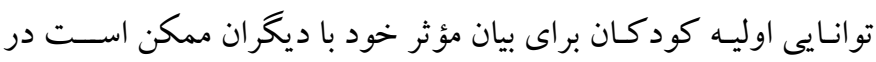
ايجاد روابط اجتماعى بهتر با ورود به تحصيلات رسمى كمكى كند (سا) ).

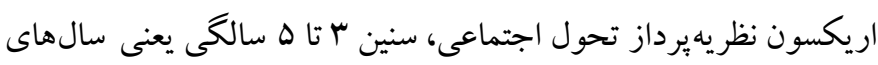

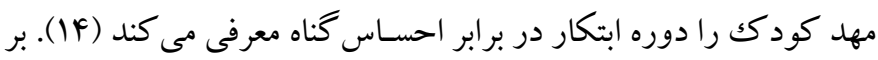

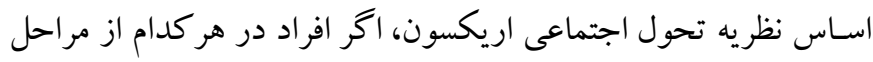

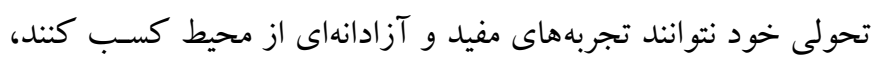

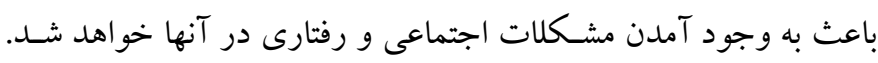

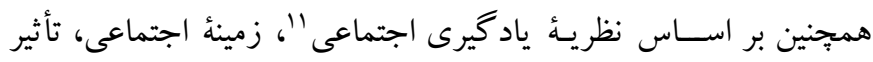

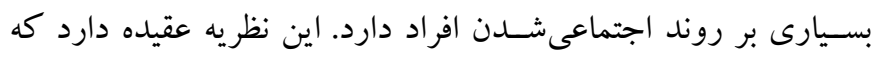
كودكان رفتارهاى اجتماعى را از طريق مشــاهده و تقليد مى آموزند

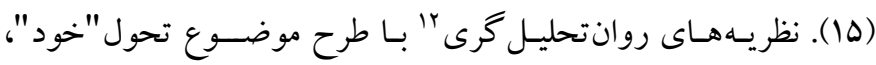

7. Assertiveness

8. Self-control

9. Preschool

10 .Hyperactive

11. Theory of social learning

12. Psychoanalysis
مقلدمه

تعامل اجتماعى'، مهم ترين جنبه وجود هر شـخص اســت (1). برقرارى ارتبـاط با ديخران نيازمند تحول مهارتهاى اجتماعى ب اســت (Y). رفتار اجتمـاعى بـايسه و اســاس زنـدكى هر فرد را تشــكيـل مىدهد و تحول اجتماعى “'نيز سـبب اعتلاى تحول ذهنى و سـاير جنبههاى تحولى فرد مى شــود (r). روابط اجتمـاعى، رفتـارى اســت كـه در مو اجهـه با محر كى اجتماعى بروز مى كند. براى كود كان مهد كودكى، ضــرورى اسـت كه مهارت هاى ارتباطى ساده را ياد بخيرند تا فرصت كاركردن با گروه را به به به عنوان يكك عضـو در گروه و همكارى با ديخران داشـته باشند. دوره مهد كودك، مرحلهاى حياتى در كسب مهارت هاى اجتماعى در تمام مراحل تحولى است (F). منابع اجتماعى شدن، افر اد و نهادهايى هستند كه در اين فرايند شـر كت مى كنند؛ مانند: والدين، خواهران و برادران، تلويزيون، و سـاير رسـانههاى گروهى. اجتماعى شــدن در بيرون از خانواده، در مهد كود كك ها و مدارس نيز ايجاد مى شود. همجينين همسالان به شكل منحصر به فرد و عمدهاى در شـكل دادن رفتار اجتماعى يكديكر سـهم دارند. از كـار كردهـاى عمـده رســانـههـا و تلويزيون نيز، آموزش اجتمـاعى بَ بـه

كود كان است (ه).

توانمنـدى هـاى اجتمـاعى - هيجـانى بـه ســرعـت در زندكى تحول مى يـابنـد. براى مثـال، تنظيم هيجـانه به طور اوليه در زمينه تعامل مادر و كودك يـاد داده مىشــود كـه ممكن اســت تـأثيرات مـادرانه را براى شـكل گيرى تحول اجتماعى - هيجانى كود كان اجازه دهد (4). يافتهاى يثوهش واحدى، فرخى و فرجيان، نشـاندهنده روند خطى قابل توجهى بين بيشرفت مهارتهاى اجتماعى و افزايش سن است كه در نتيجه باعث كاهش مشـكلات اجتماعى كود كان ب تا ها سـال و 9 ماهه مي شـود (V). نتـايج يزوهش يـاســمى، كيـان، و گ زرامى يور و همكاران نيز نشــان داد ميانگين نمرات مهارت هاى اجتماعى در كود كان بيش دبستانى F تا ه سال شــهرســان ايوانغرب، بيشتر از ميانخين فرضسى جامعه (ه/ •) بود؛ به عبارتى، نتايج حكايت از توانايى بيشتر كود كان در مهارت هاى اجتماعى

1. Social interaction

2. Social skills

3. Social development

4. Social education

5. Emotion

6. Control group 
با سـازمان بهزيستى و اخذ مجوز از ايشان، از روش نمونه گيرى خوشهاى

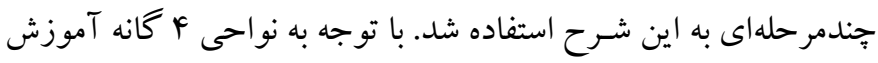

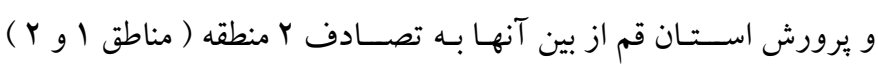

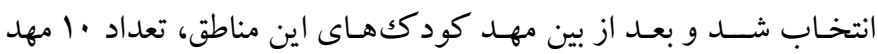
كودكك ( در مجموع ه مهـد كود كك دخترانه و هـ مهد كودكك يســرانه)

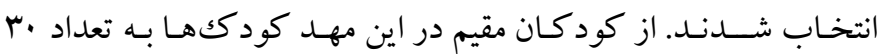

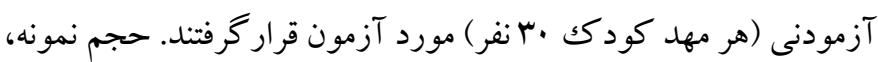

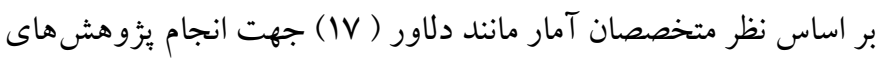

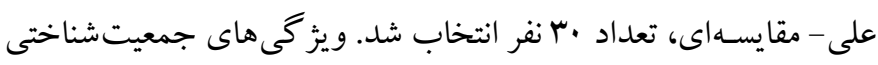

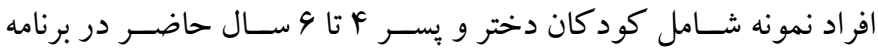

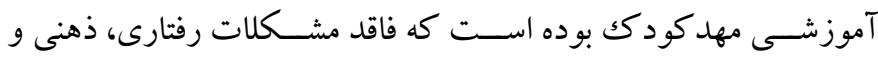

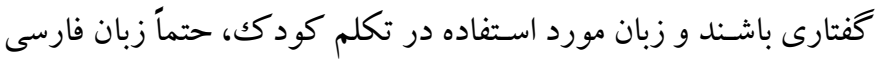
باشـد؛ هر جند كه ممكن اسـت كود كك به زبان ديخرى نيز تسـلط داشته

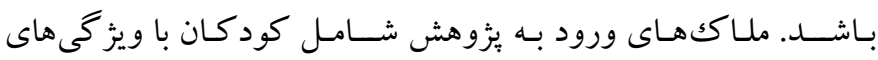

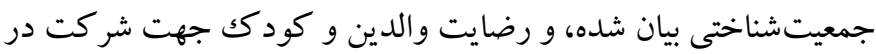
مطالعه بوده است. ب) ابزار ا. زيرمقياس ارتباط اجتماعى /ز آزمون سنجش تحول شناخت، ارتباط

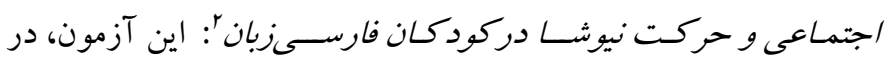
يزوهشى توسط جعفرى، عشايرى، ملايرى و علاءالدينى با هدف ساخت

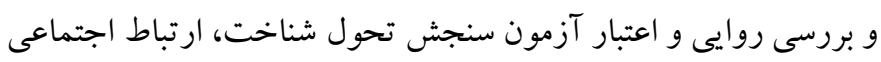

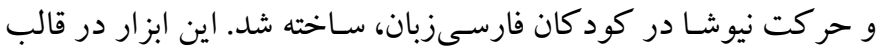
rا جدول تحولى در محدودههاى سنى از تولد تا V VI ماهكى تنظيم شده

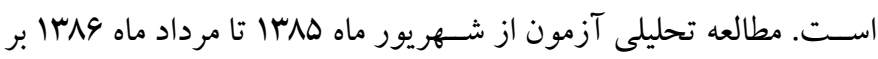

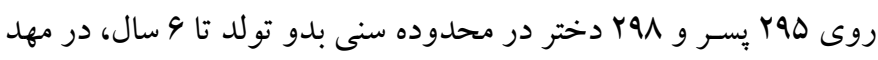
كود ككهاى اسـتان تهران به صسورت خوشـهـاى انجام شــد. مواد آزمون

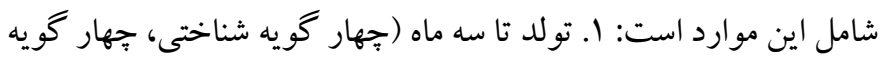
ارتباط اجتماعى، شـش گويه حركتى)، ז. جهار تا شـش ماه (جهار كويه

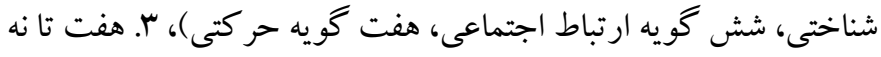

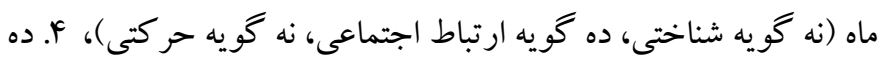

2. Newsha cognitive, social communication \& motor development scale in persian speaking children
رفتـارنغرى بـا طرح تقويـت، تـداعى، و شـكـل گيرى رفتـار، و حتى

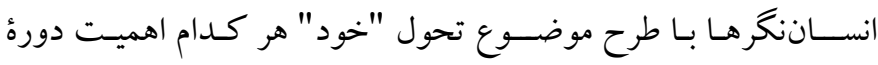

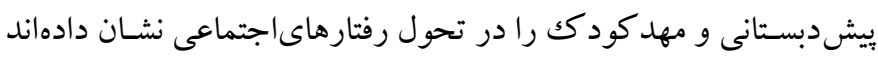

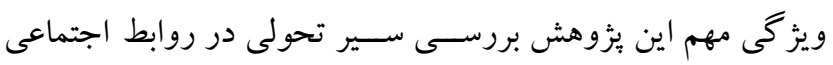

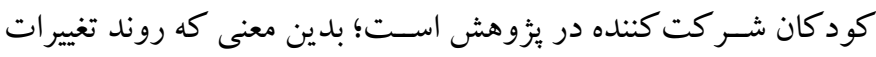

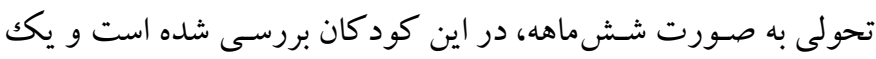

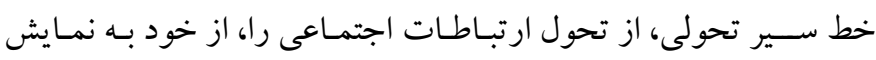

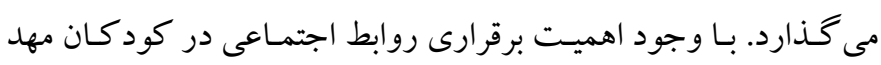

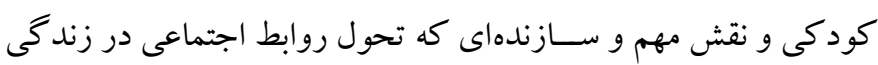
حال و آينده كودك دارد، اما تاكنون مطالعهاى به بررسى همه نهانبه تأثير ونه

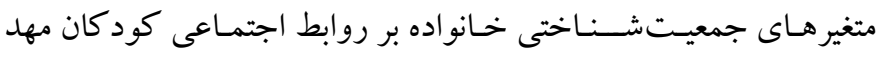

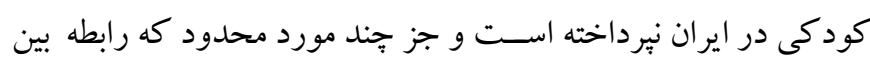

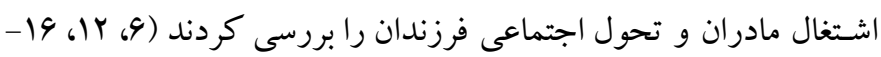

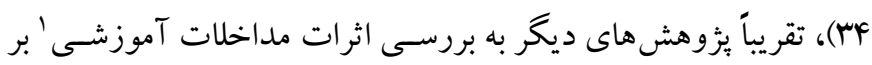

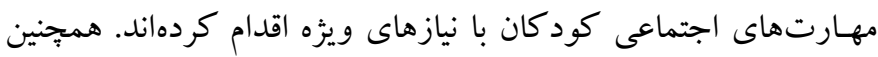

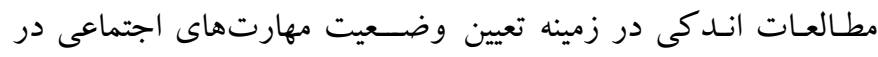

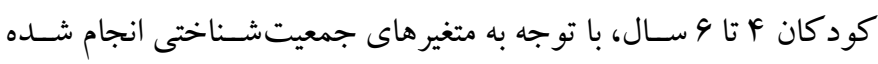

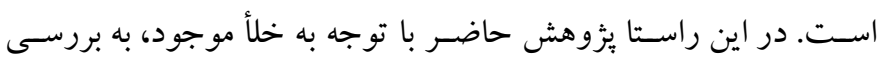

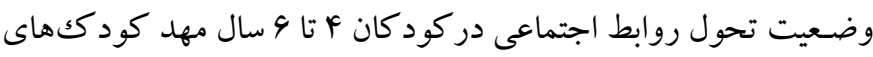
اسـتان قم بر اسـاس وضسعيت جمعيت شــاختى خانو ادهها در سـال هوسا

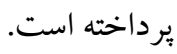

روش الف) طرح مطالعه و شر كت كنند كان: يُزوهش حاضر از نظر هدف از نوع يزوهشهـاى كـاربردى بوده و از نظر مـاهيت، جزء ئزوهشهاى كمّى و از نظر روش يُزوهش از نوع يُزوهش هاى على - مقايسهاى است.

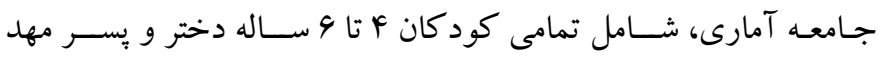

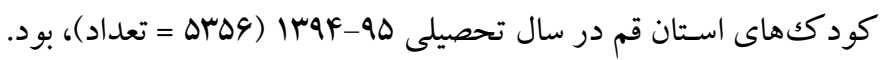

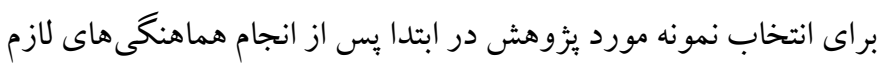

1. Educational intervention 
تحولى (اعتبـار بين آزمونخر r) در مقيـاس شـــــاخـت بوه/، در مقيـاس

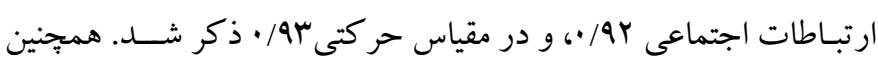

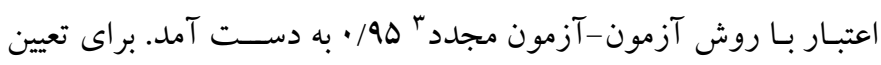

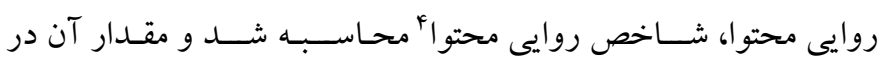

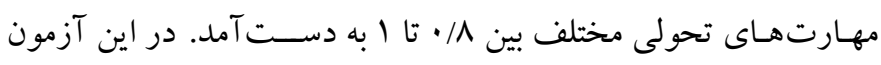

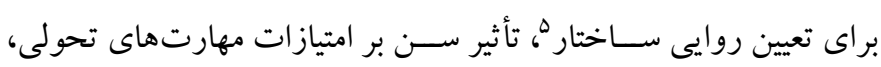

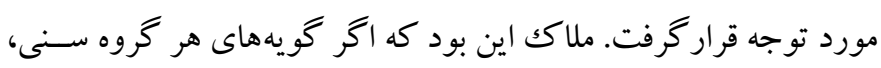

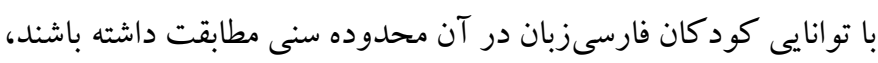

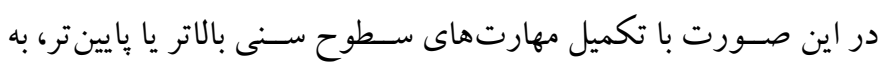
ترتيب عدم كسـب امتياز للام يا كسـب امتياز كامل تر در بيشتر كود كان،

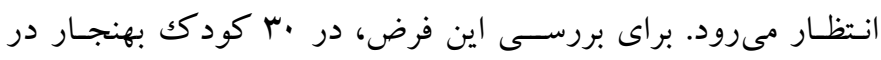

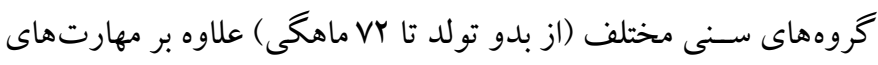

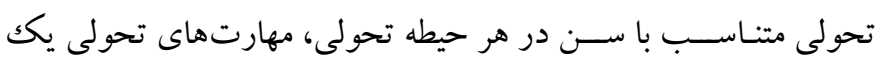

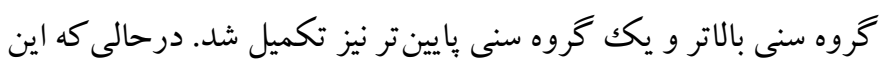

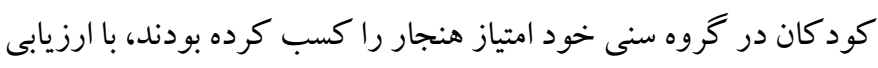

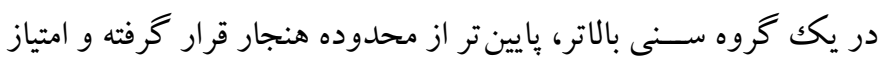

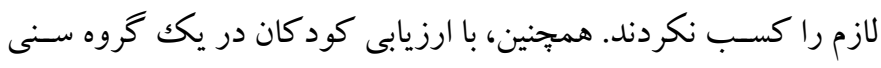

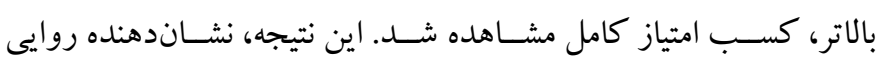

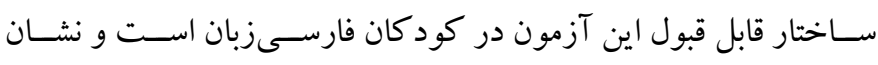

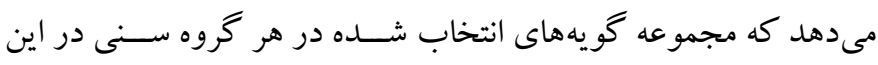

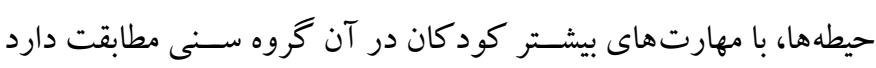

r. آزمون دموكرافيك محققساخته: اين برسـشنامه داراى سؤ الاتى در مورد: ا. ميزان تحصسيلات بدران شـامل: الف. بىسـواد، بـ بـ ابتدايى، ج. ج.

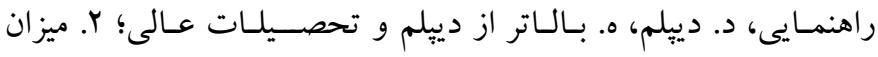

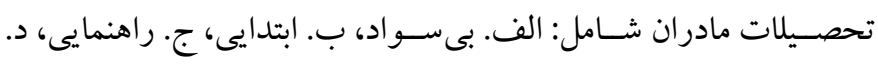

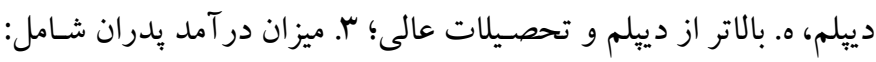

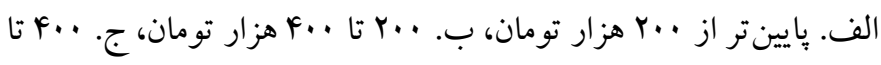

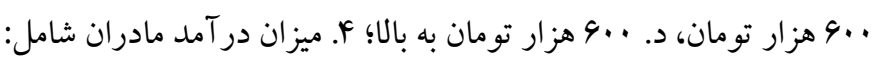

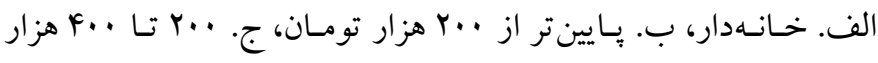

4. Content validity index

5. Construct validity

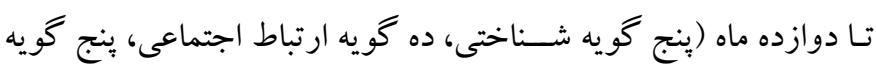

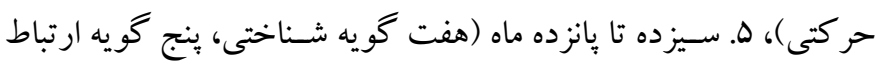

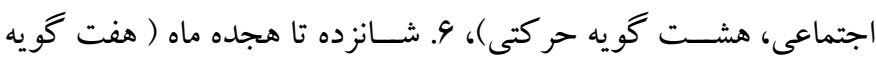

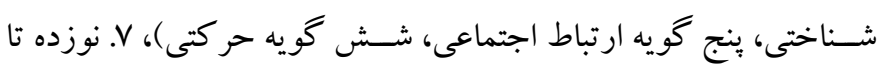

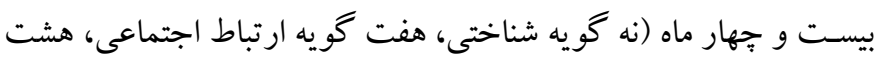

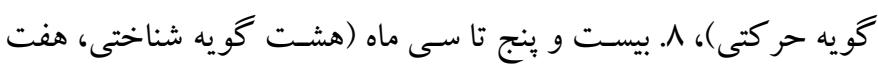

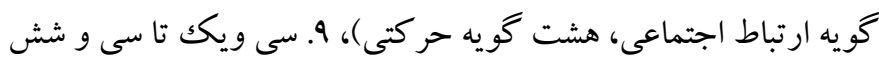

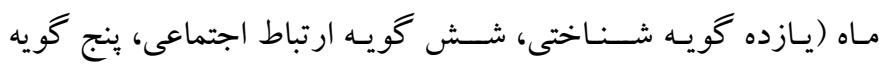

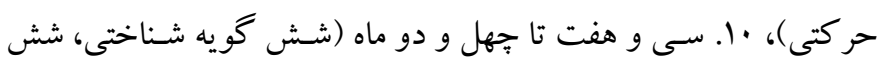

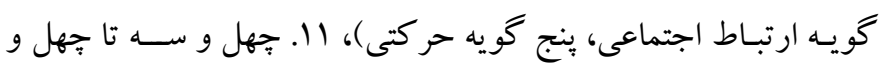

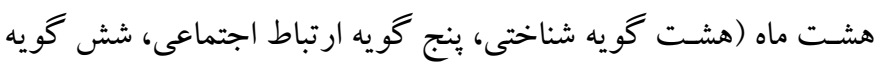

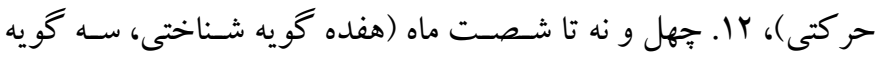

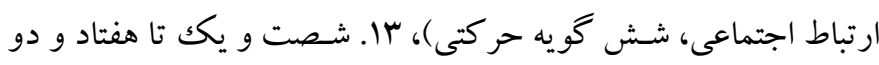

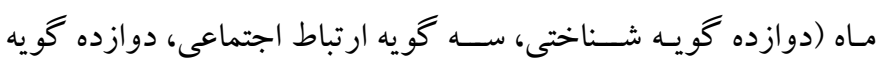
حر كتى). در اين آزمون، براى تفسير نتايج هر يكك از سطوح تحولى، از معيار

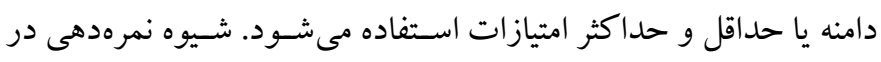

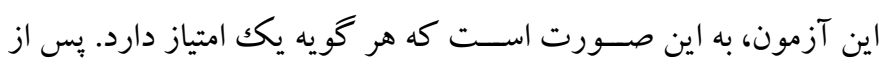
تكميل آزمون در هر سـطح تحولى، در صسورت كسـب امتياز حداقل و

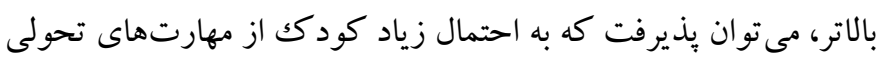

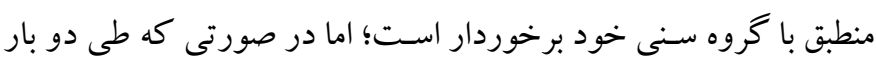

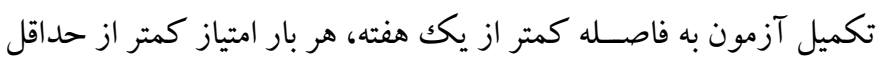

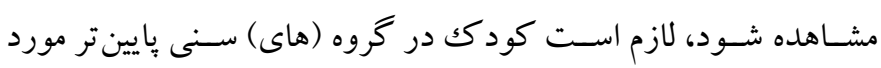

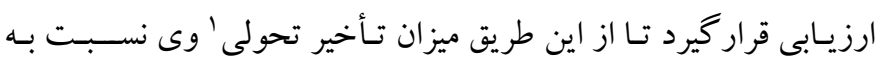
كود كان همسن طبيعى در حيطه تحولى مورد نظر، مشخص شود. در اين آزمون نيز براى تعيين تأخير تحولى احتمالى در صورت عدم كسب امتياز

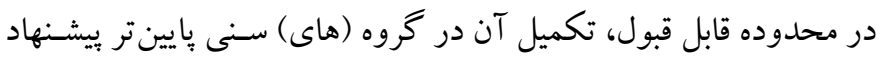

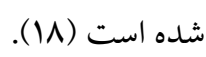
در اين آزمون، اعتبار نتايج حيطههاى تحولى تدوين شــده، با روش

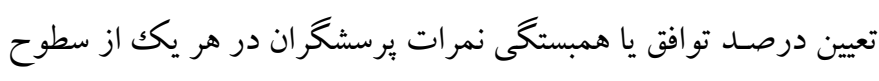

1. Developmental delay

2. Inter-rater reliability

3. Test - retest 
شــاخت، ارتباط اجتماعى و حركت نيوشــا در كود كان فارسـىزبان از

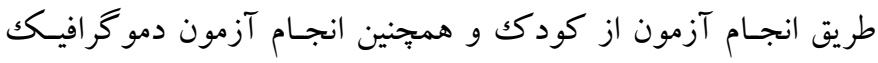

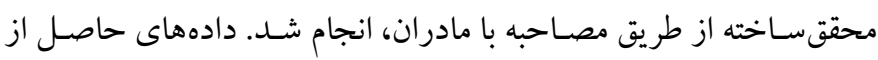

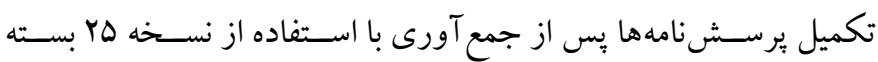

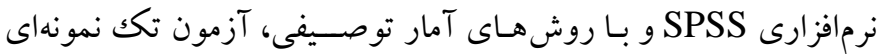

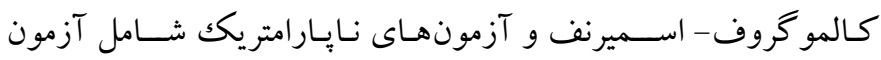
نمونه هاى مستقل كروسكال- واليس و آزمون نمونه هاى مستقل يومان ويتنى، تحليل شد.

\section{يافته ها}

در جدول ا، شـاخصهاى توصيفى شاخصهاى آمارى مربوط به تفاوت

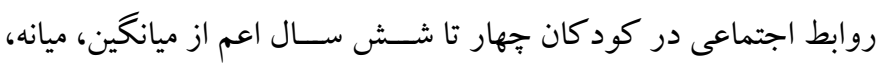

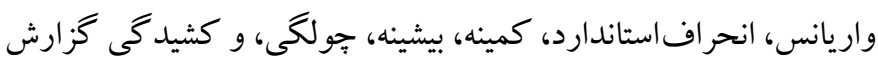

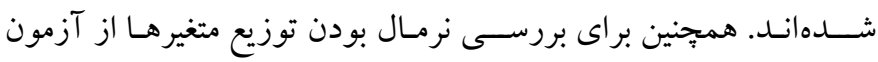

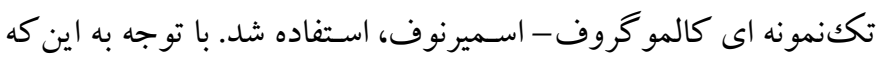

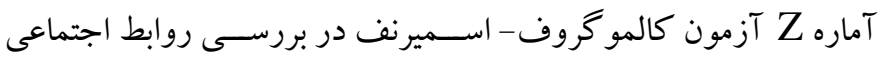

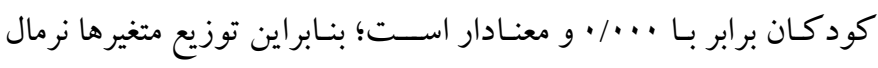

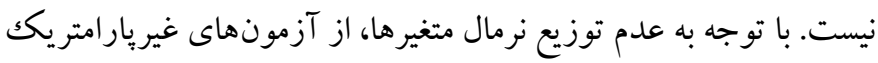

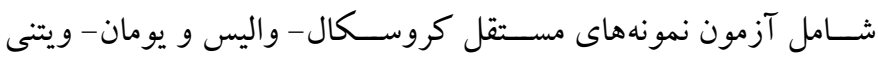

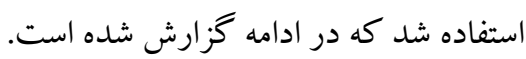

تومان، د. ..F تا ..9 هزار تومان، ه. ..9 هزار تومان به بالا؛ ه. وضسعيت مسـكن خانو اده شـامل: الف. شـخصى، ب. اسـتيجارى، ج. ـ سازمانى، د. سـايرموارد؛ 9. سـابقه جدايى يا از دست دادن والدين و يا عزيز ان شامل: الف. بلى، ب. خير؛ V. سـابقه مشكلات روانيزشكى ئه يدر و مادر، شامل.

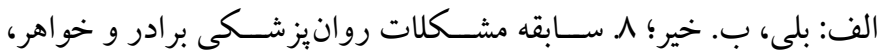

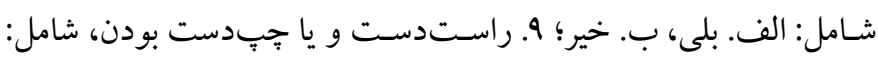

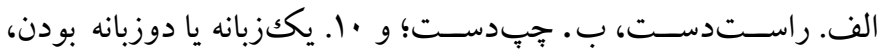

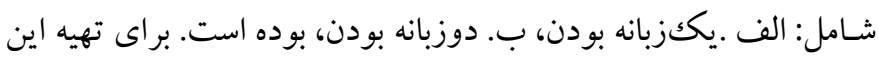
يرسش نامه از متون درسى، يُزوهش هاى بيشين، و برسش نامه هاى مشابه در باياننامهها اسـتفاده شـده است و تكميل آن توسط مادر كود كك انجام

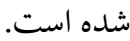

ج) روش اجرا: در مرحله اول يُزوهش، بِ از كسب مجوزهاى للازم از

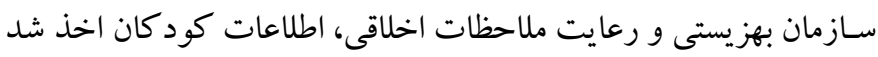
و بـا مراجعه به مهد كودككهاى منتخب، با توجه به ملاككهاى ورودى،

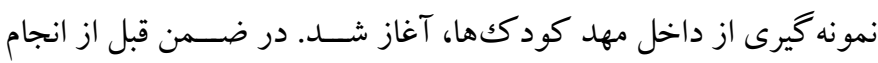

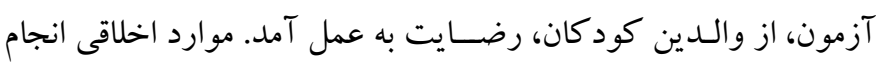

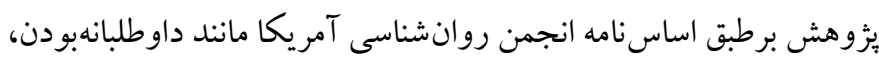

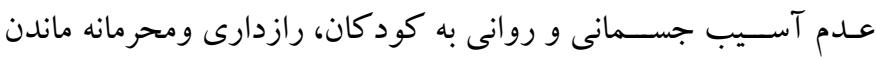

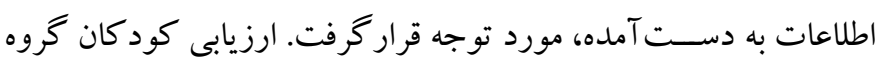

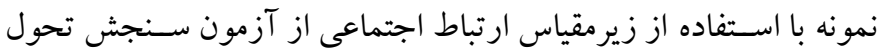

\section{جدول ا: خلاصه شاخصهاى آمارى مر بوط به تفاوت روابط اجتماعى در كود كان جهار تا شش سال}

\begin{tabular}{|c|c|c|c|c|c|c|c|c|}
\hline كشيدكى & جولَّى & بيشينه & كمينه & انحراف معيار & واريانس & ميانه & ميانكين & سن \\
\hline l/ADF & $-1 /$ YqY & $\mid r / \cdot \cdot$ & $\cdot / \cdots$ & r/arVar & N/GTI & $9 / \ldots$ & $q / r \Delta \ldots$ & F سالكى F \\
\hline$-\cdot / 9 \vee 9$ & $-\cdot / \Delta \Delta r$ & $10 / \cdot$. & $\Delta / \cdot \cdot$ & r/VI994 & $|r / A| F$ & $1 . / \ldots$ & $11 / \Delta \ldots$ & F/ه سالكى \\
\hline $1 / 9 V 9$ & $-I / Y F$. & $10 / \cdot$. & $\cdot / \cdot$ & $r / a r \Lambda \cdot \Lambda$ & $1 \Delta / \Delta \cdot \Lambda$ & $1.1 \ldots$ & $11 / \Delta \ldots$ & هـ سالكى \\
\hline r/raq & $-1 / 99$. & $10 / \cdot$. & $\%$ & r/YrVYFa & $1 \cdot / F I V$ & $10 / \cdots$ & $|Y / 9| 9 V$ & ه/ه سالكى \\
\hline$\Delta / r r \Delta$ & -Y/MIN & $10 / \cdot$. & $\cdot / \cdot$ & $\Gamma / \Lambda \cdot \Delta \wedge \Delta$ & IF/FAF & $10 / \ldots$ & $\mid r / \cdot \Delta r r$ & 9 سالكى \\
\hline
\end{tabular}

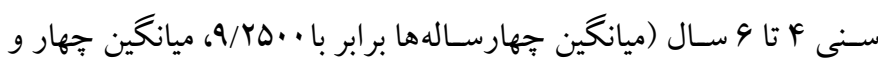

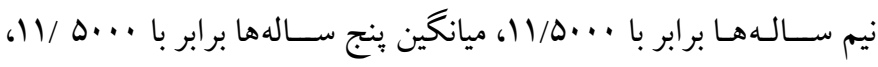

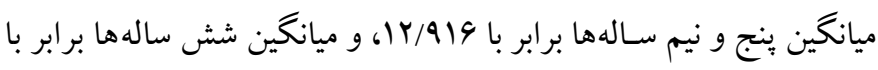

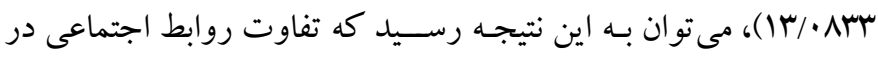

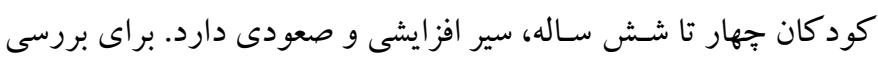

با توجه به نتايج حاصـل از جدول ا، در مورد بررسى تفاوت روابط اجتماعى در كود كان جهار تا شـش ســاله، بر اسـاس شـاخصهاىهاى

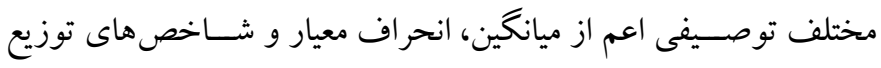

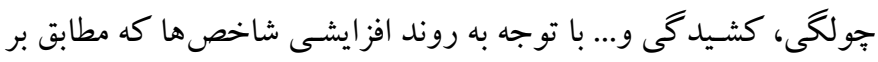

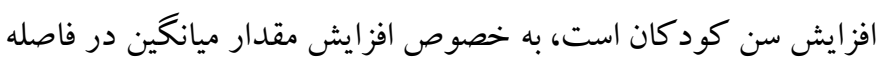




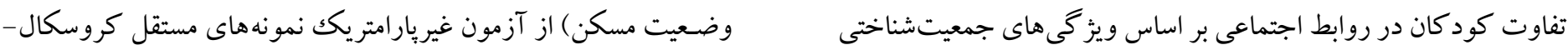

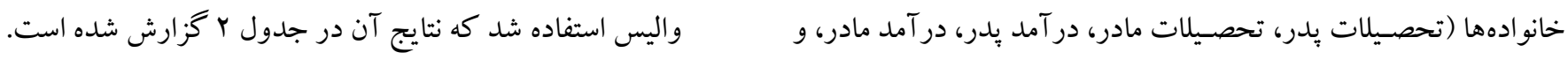
جدول r: نتايج آزمون نمونه هاى مستقل كروسكال- واليس جهت بررسى تأثير برخى از متغيرهاى جمعيتشناختى در روابط اجتماعى كودكان

\begin{tabular}{|c|c|c|c|c|c|}
\hline معنادارى & درجه آزادى & آماره آزمون & ميانكين روابط اجتماعى & فراوانى نفر) & متغير \\
\hline \multirow{4}{*}{ - /VIF } & \multirow{4}{*}{$r$} & \multirow{4}{*}{$1 /$ rar } & r/9Y & ابتدايى & \multirow{4}{*}{ ميز ان تحصيلات يدران } \\
\hline & & & $r / 94$ & راهنمائى & \\
\hline & & & $r / 99$ & دييلم 19 & \\
\hline & & & $r / F V$ & 199 & \\
\hline \multirow{5}{*}{$\cdot / \Delta V F$} & \multirow{5}{*}{ r } & \multirow{5}{*}{$r / 9 \cdot F$} & r & بى بـواد & \multirow{5}{*}{ ميزان تحصيلات مادران } \\
\hline & & & $r / \Delta$. & ابتدايى & \\
\hline & & & r/qT & راهنمائى & \\
\hline & & & $r / 91$ & qF & \\
\hline & & & $r / \Delta F$ & 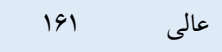 & \\
\hline \multirow{4}{*}{-/V94 } & \multirow{4}{*}{$r$} & \multirow{4}{*}{$1 / \cdot r F$} & $r$ & 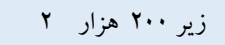 & \multirow{4}{*}{ ميزان درآمد يدران } \\
\hline & & & $r$ & $1 \quad r \cdot . \cdot r .$. & \\
\hline & & & $r / \Delta \Lambda$ & ir $q . . b r .$. & \\
\hline & & & $r / \Delta V$ & YAD T به بالا & \\
\hline \multirow{5}{*}{$\cdot / 4 V q$} & \multirow{5}{*}{ r } & \multirow{5}{*}{$r / 4 q}$. & $r / \Delta \Delta$ & خانهدار IVr & \multirow{5}{*}{ ميزان درآمد مادران } \\
\hline & & & $r / r r$ & زير ·. هزار 9 & \\
\hline & & & r/VQ & $f \quad r \cdot . r r .$. & \\
\hline & & & F & $19 . . t k .$. & \\
\hline & & & r/gr & IIV وبه بالا . . & \\
\hline \multirow{3}{*}{. } & \multirow{3}{*}{ r } & \multirow{3}{*}{ r/YIV } & $r / \Delta \Delta$ & HFF شخصى & \multirow{3}{*}{ وضعيت مسكن خانواده } \\
\hline & & & r/9T & استيجارى FV & \\
\hline & & & $r / M$ & ساير & \\
\hline
\end{tabular}

متغير در روابط اجتماعى، معنادار نيست (p99/ > p)؛ متغير ميزان در آمد

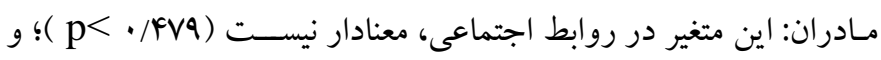
متغير وضــيـت مسـكن خانواده: اين متغير در روابط اجتماعى، معنادار نيست ( •بس/•>p ). در جدول ب نتايج آزمون نمونه هاى مستقل يومان-

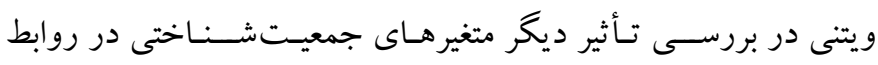
اجتماعى كود كان كزارش شده است.
همـان طور كـه در جــدول فوق مشـــاهـده مىشــود تـأثير برخى از

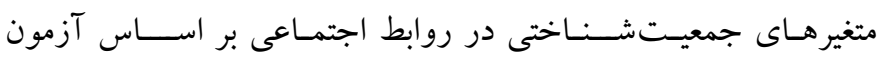
غيريارامتريكك نمونه هاى مستقل كروسكال- واليس به شرح زير است:

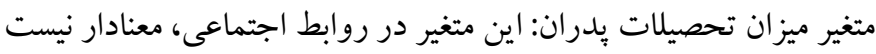
(p<•/VIF)

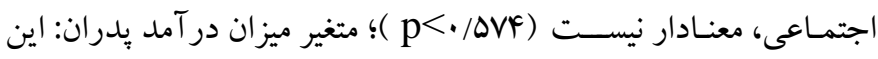


جدول זّ: آزمون نمونهاى مستقل يومان-ويتنى در بررسى تأثير ديكر متغيرهاى جمعيتشناختى در روابط اجتماعى كودكان

\begin{tabular}{|c|c|c|c|c|c|c|c|c|}
\hline معنادارى & آسارهارهارآمون شده & خطاى استاندارد & آماره آزمون & يومان ويتنى & ميانكين روابطاجتماعى & (نفر) & فراوانى & متغير \\
\hline . & - /VAF & $11 \cdot / \mu q q$ & MAF/Q . & MFN/Q .. & $\begin{array}{l}r / \cdot \\
r / \Delta \Lambda\end{array}$ & $\begin{array}{l}r \\
r a \Lambda\end{array}$ & خير & سابقه جدايى يا از \\
\hline$\cdot / \mathrm{VAA}$ & $\cdot / r \cdot 1$ & $11 \cdot / r F q$ & rTr/... & rrr/... & $\begin{array}{l}r / \Delta \cdot \\
r / \Delta \Lambda\end{array}$ & $\begin{array}{l}r \\
\text { ran }\end{array}$ & خلى & روان شوابقه مشكلات \\
\hline$\cdot / R \Delta 1$ & $-\cdot / 9 T Y$ & $r \cdot \% / 990$ & $191 \mathrm{~N} / \ldots$ & $1941 / \cdots$ & $\begin{array}{l}r / D \Lambda \\
r / F F\end{array}$ & $\begin{array}{l}\text { YAF } \\
19\end{array}$ & 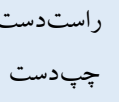 & 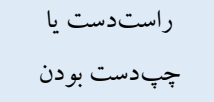 \\
\hline$\cdot / 9 \cdot v$ & $-\cdot / 1 \mathrm{VV}$ & FYF/TAG & $r r \Delta q / \ldots$ & froq/... & $\begin{array}{l}r / \Delta A \\
r / \Delta r\end{array}$ & rGV & يككزبانه & يكك يا دوزبانه بودن \\
\hline
\end{tabular}

نيسـت. دادستان و همكاران در بزوهش خود نشان دادند كه برسش نامه

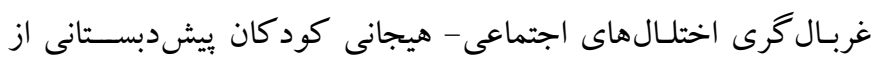

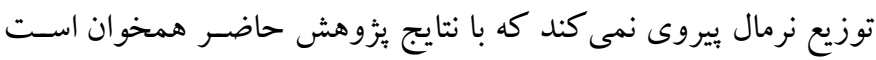

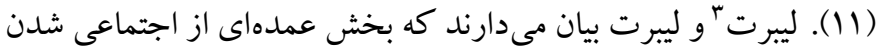

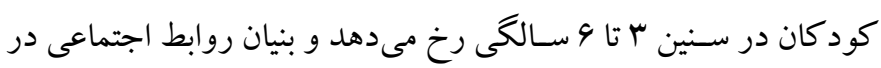

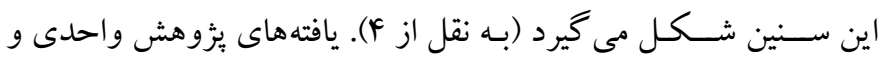

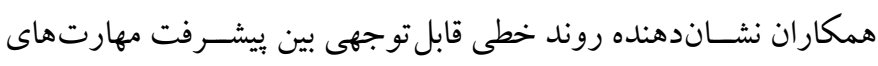

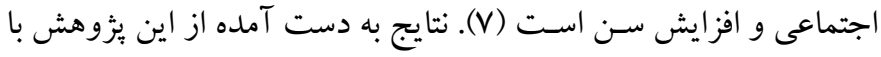

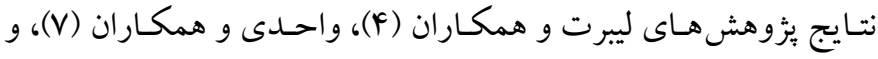

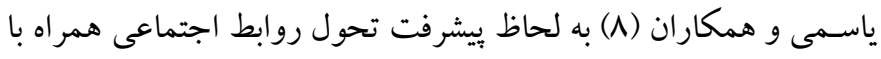

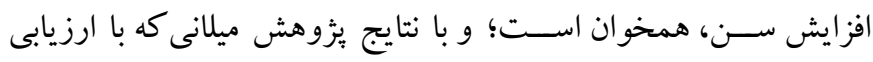

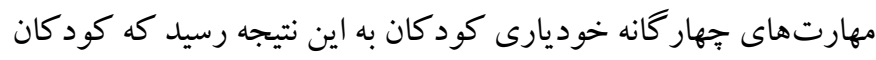

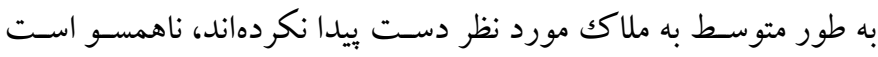

در تحليل اين موضسوع كه"روابطاجتماعى" كود كان شـركت كننده

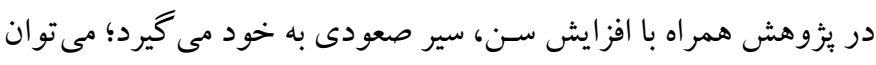

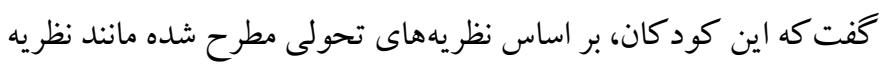

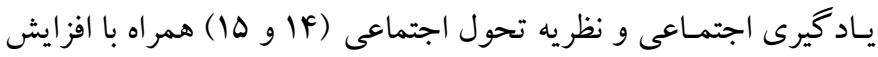
سن و با توجه به اصول خاص تحولى اين دورهو همجنين تأثيريذيرى از

3. Libert
بـاتوجسه بـه نتـايج حـاصــل از جــول س، تـأثير ديخر متغيرهـاى جمعيـتشــــاختى در روابط اجتمـاعى كودكـان بر اســـاس آزمون نايار امتريكك نمونه هاى مستقل يومان- ويتنى، به شرح زير است:

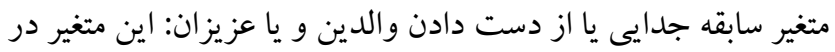

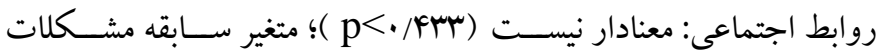
روانيزشـكى والدين: بر اسـاس خلاصسه شـاخص هاى آمارى در آزمون،

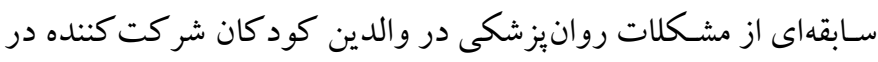

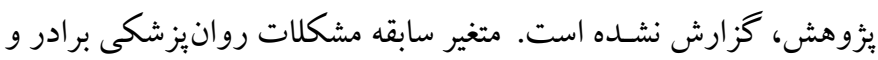

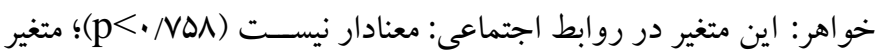
راسـتدست و يا جِبدست بودن: اين متغير در روابط اجتماعى: معنادار

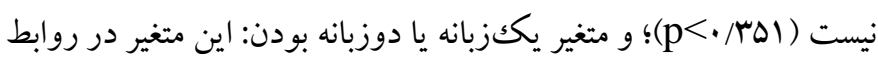

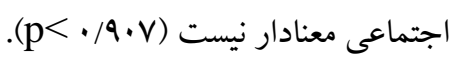

\section{بحث و نتيجه كيرى}

اين يُزوهش به منظور تعيين سطح تحول روابط اجتماعى كود كان F تا 4

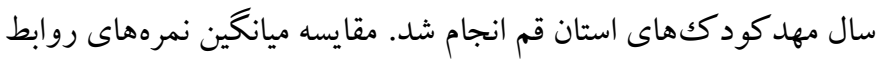

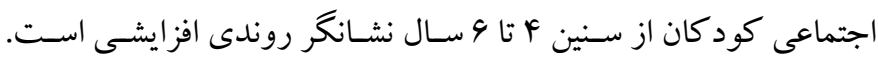

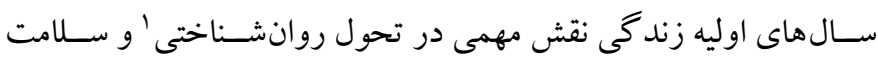

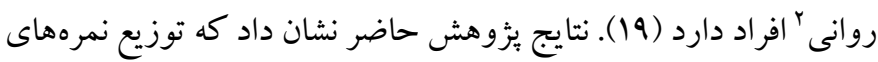
تحول روابط اجتماعى كود كان جهار تا شـش سـال داراى توزيع نرمال

1. Psychological

2. Mental health 
سـال هـا نيـاز به محيطى بر انخيز اننده دارد كه نقش مهد كود ككها را در يرورش كود كان نشان مىدهد (YF) به طور كلى نتايج يزوهش حاضر نشانگر روند افزايش سطح تحول

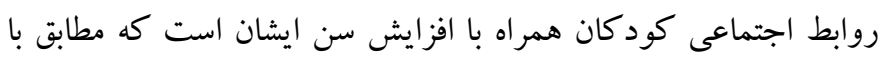

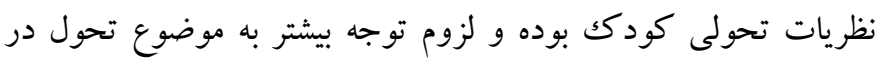

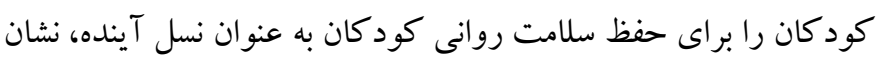
مى دهد. انجام اين يزوهش كامى در جهت ارتقاء سلامت كودكى، با نكاه

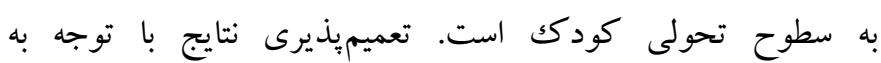
محدوديتهاى نمونه آمارى و عدم نمونه گيرى از كودكان غير مهد كود ككرو، بايد با احتياط انجام شود.

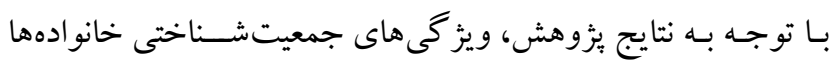

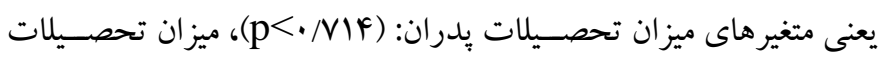
مـادران (p/DF)

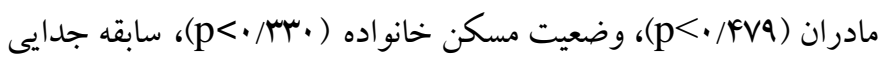

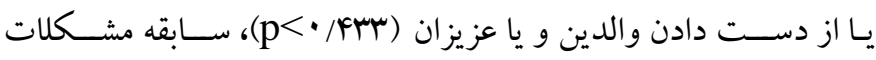

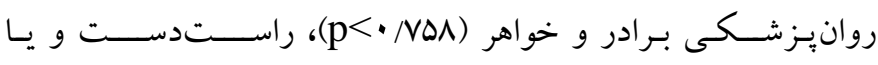

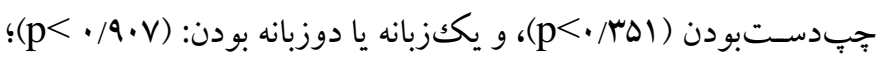
در روند روابط اجتماعى كود كان مؤثر نيست. مطالعات متعددى در زمينه

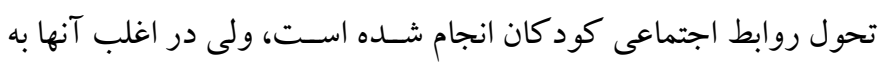

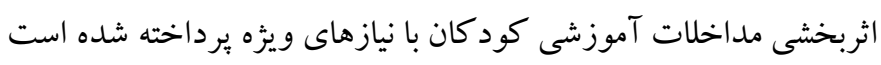
و فقط جنــ مورد مححدود كه به بررسـى رابطه اشـتغال مادران با تحول

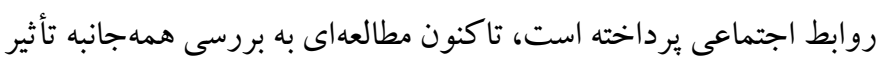
متغيرهـاى جمعيـتشــناختى خانو اده بر تحول روابط اجتماعى كود كان مدان

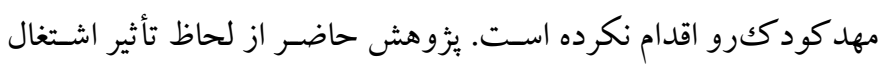

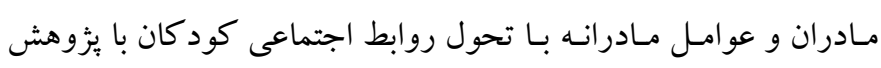

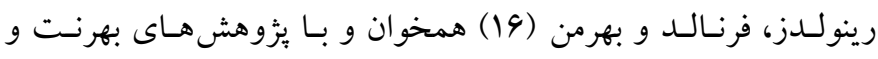

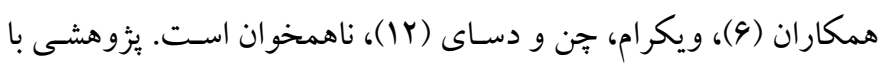

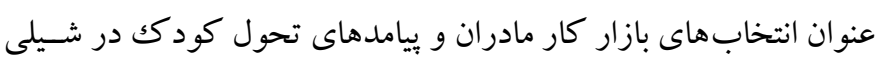

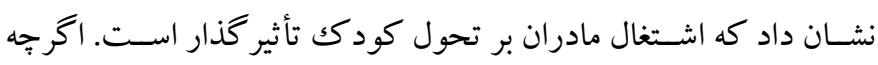

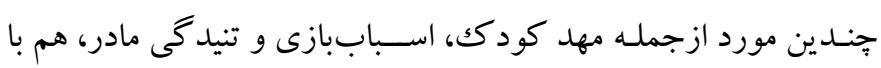

محيط مهـد كودك و مسـائـل مربوط به آن مانند آموزشهاى مربوطه،

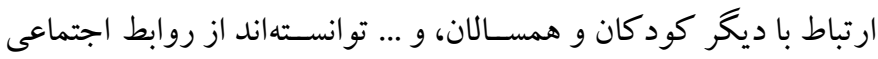

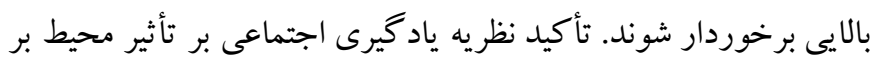

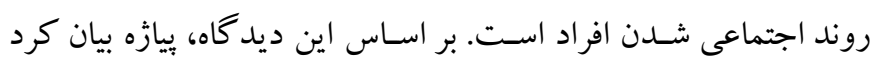

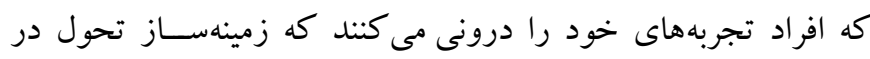
حيطههاى مختلف اعم از تحول اجتماعى خواهد شــــ افزون بر اين، بندورا معتقد بود كه افراد بدون تقويت بيرونى نيز مى توانند از طريق

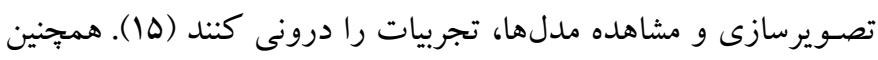

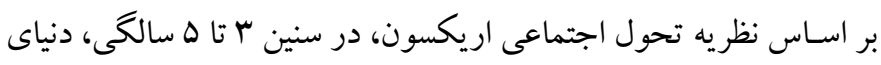

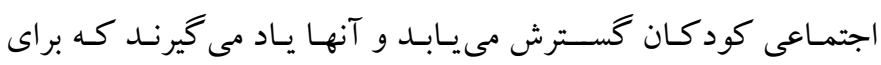
كنار آمدن با كشاكش ها، هدفمند رفتار كنند (IF) (IF).

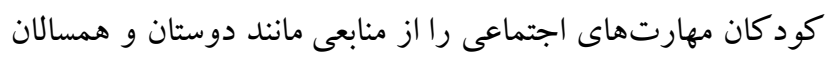

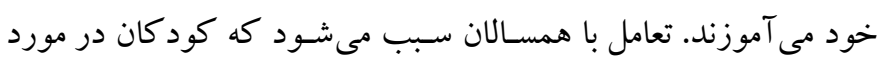

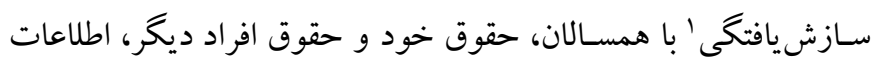

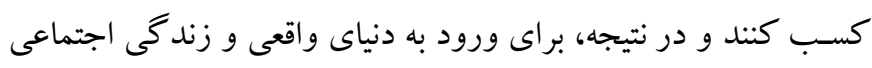

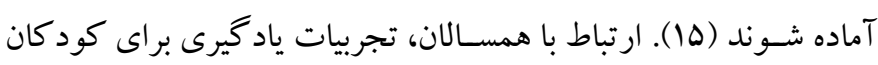

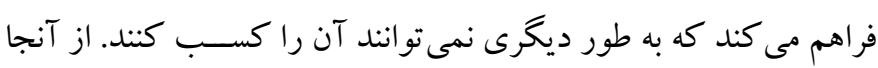

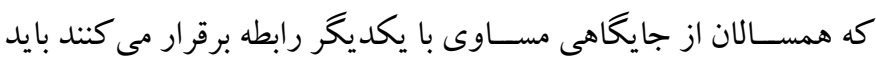

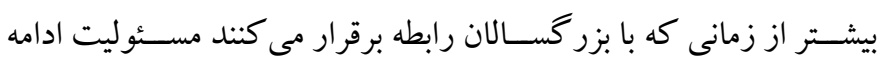

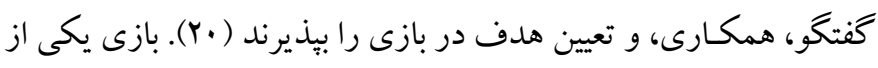

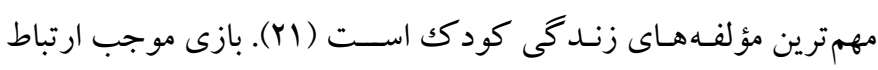

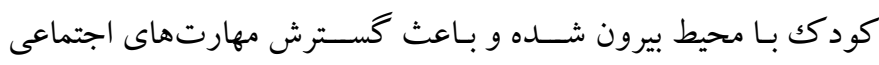

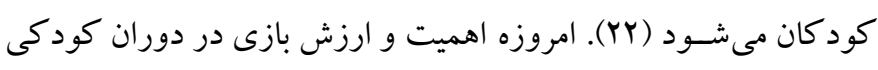

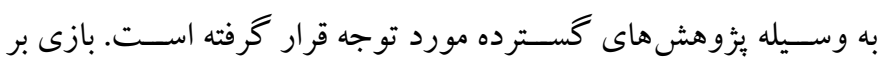

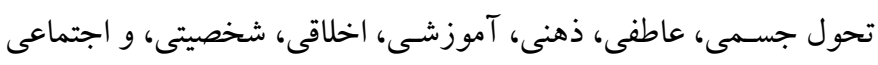

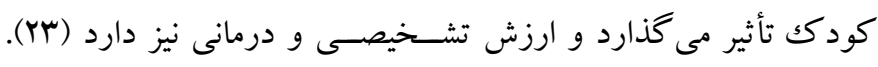

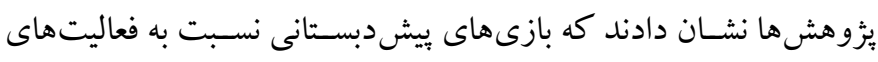

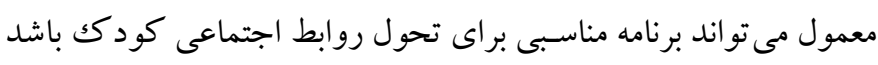

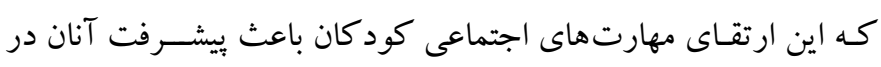

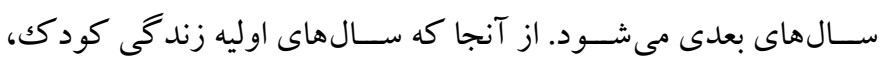

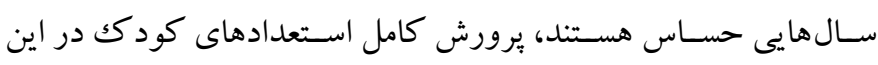

1. Adjustment 
تحول "خود" (F)، اين گونه تبيين كرد كه شـايد بهرهمندى اين كود كان

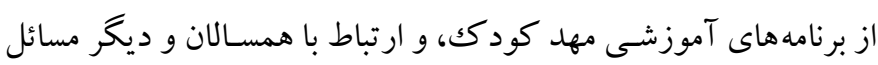
مهد كودك، تأثيرى مهم در تحول روابط اجتماعى ايشـان داشسته اسـت.

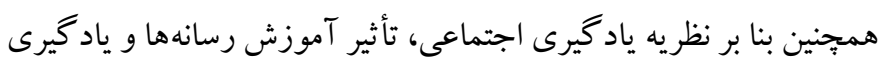

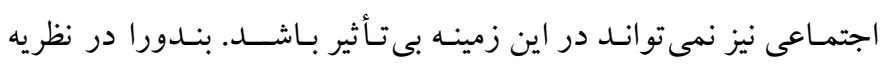

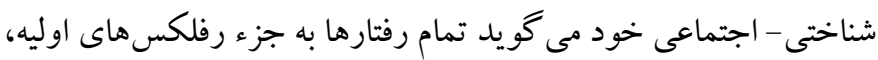

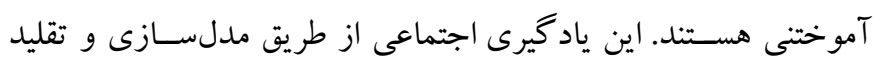

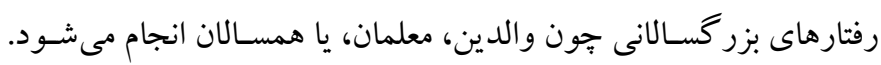

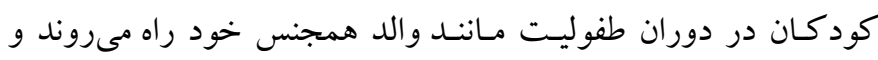

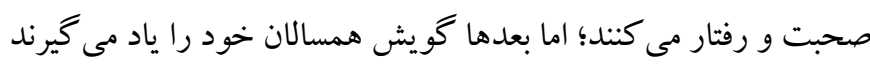
و در صحبت از آنها بيروى مى كنند (^). رسانهها از جمله منابع مهم اجتماعى كردن كود كان هستند. تلويزيون از همان آغاز زندكى كود كان، نقش مهمى در اجتماعى كردن من آنان دارد؛

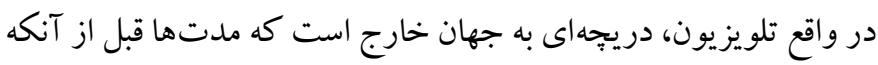

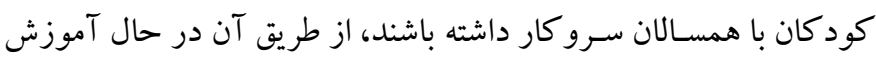

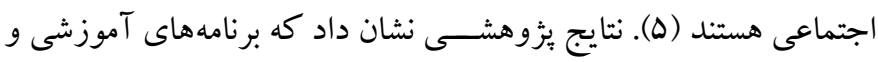
يرورشى حاكم بر مراكز بيشدبستانى و مهد كود ككها، با وجود اينكه از بهاز

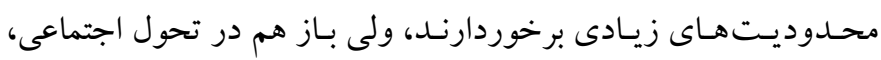

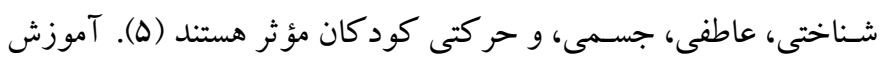

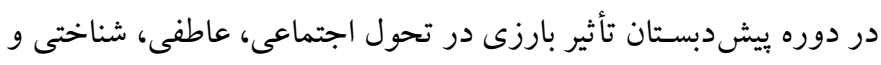

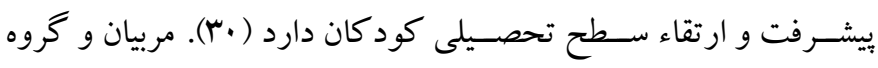

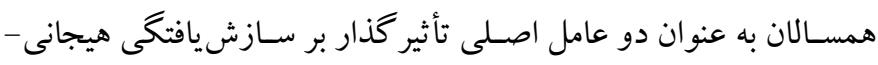

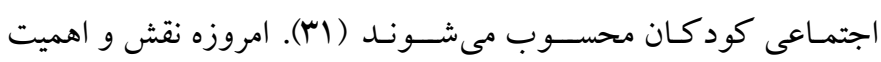
شخصيت مربيان در برورش استعدادها و توانايىهاى كود كان مورد تأييد

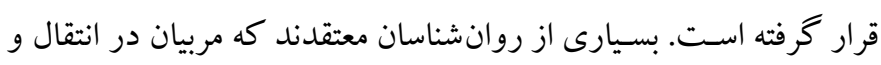
يـاد كيرى مفاهيم و گســترش توانايى ذهنى كود كان ســهم زيادى ايفاء

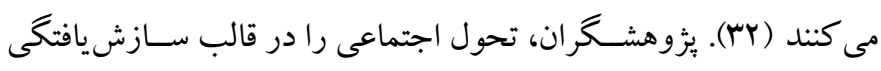

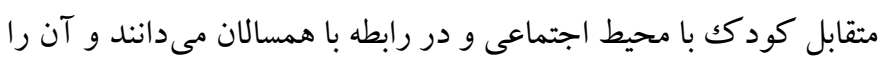

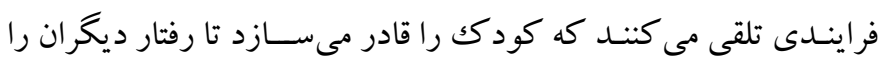
دركك و ييشبينى، رفتار خود را مهار، و تعاملات اجتماعى را تنظيم كند

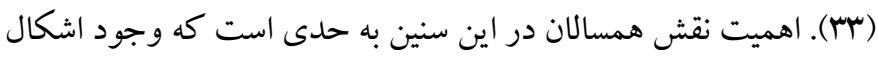

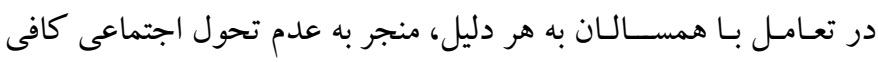

اشتغال مادران و هم با نتايج تحولى كود كان ارتباط دارد، اما اين موارد به

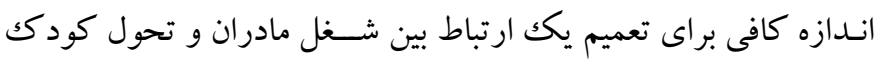

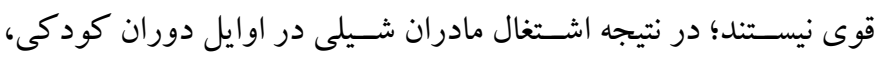

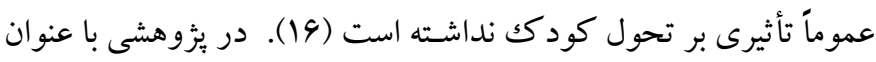

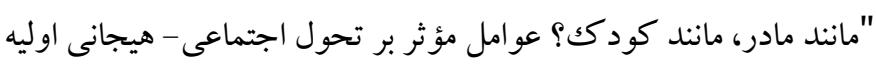

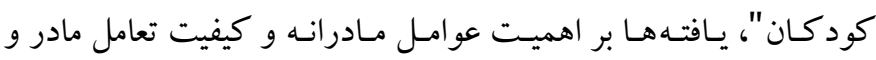
كودك براى ايجـاد تحول مثبت كود كان تأكيد داشــتند (9). در مطالعه

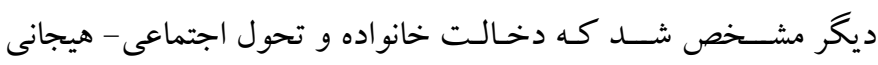

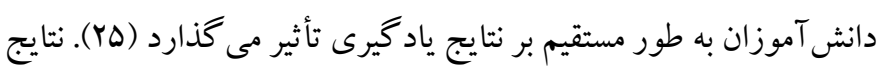
همه اين مطالعات به طور ضمنى با يافته هاى اين مطالعه همخوان هستند. نتايج يزوهش افلاطونيان، علم، محمدى يورنجيب و محمدزاده نشـان بـ بـان

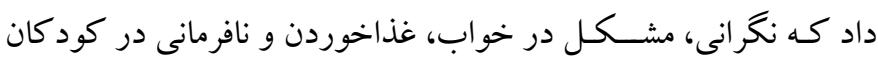
مـادران شــاغل، و عصــبى بودن در كود كـان مـادران خـانهدار به طور

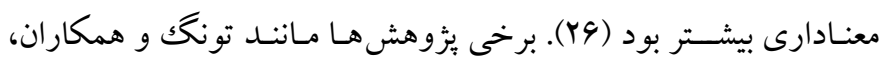

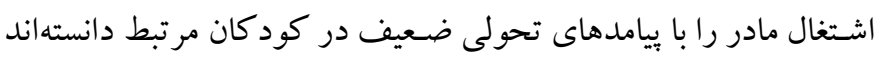

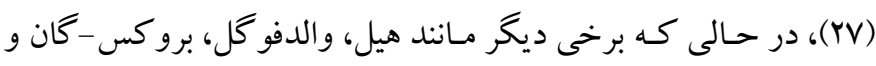

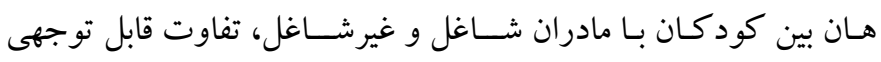

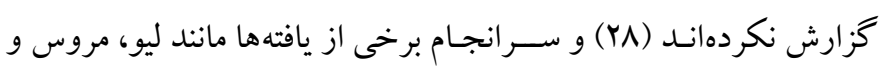
وندر كلاو نيز ييامدهاى بهترى را نصـيب كود كانى دانسـتهاند كه مادران

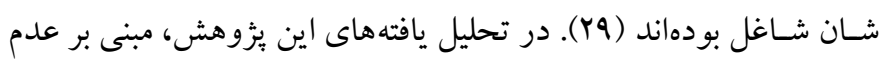

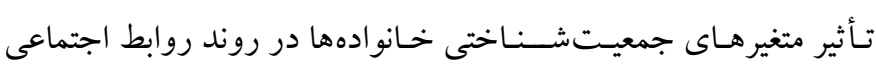

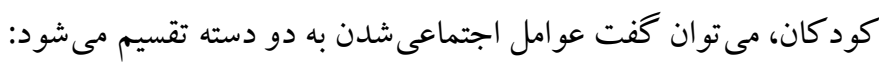

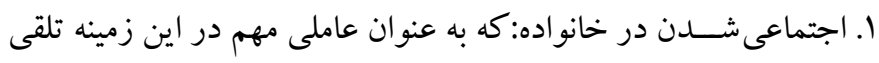

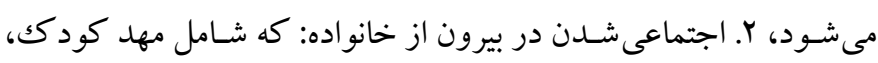

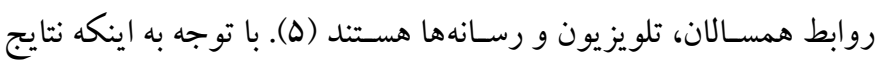
يزّوهش حاضـر حاكى از عدم تأثير متغيرهاى جمعيت شــاختى خانو ادهها

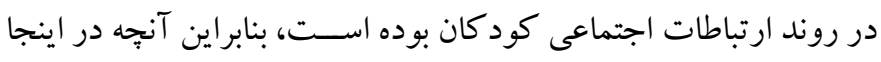

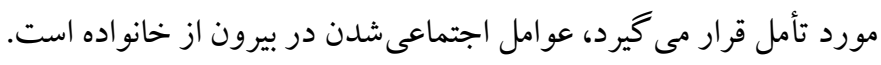

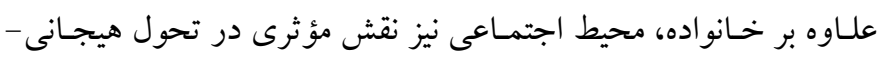

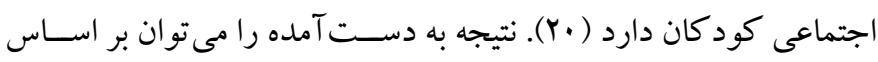

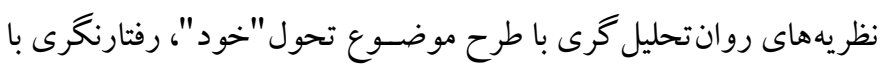

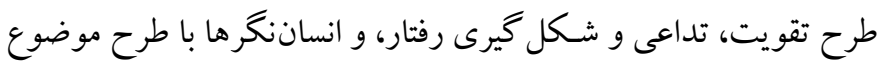


انجام شود تا سبب تعميم يذيرى بيشتر نتايج اين يزوهش شود. با توجه به

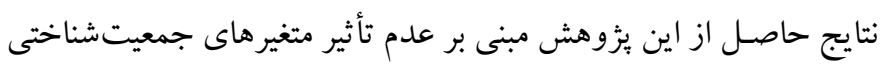

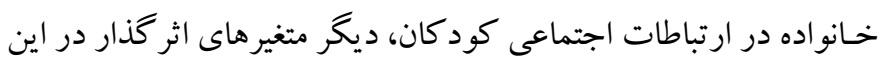

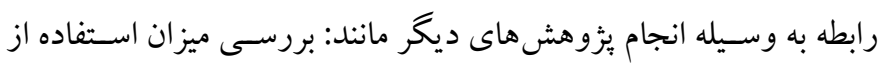

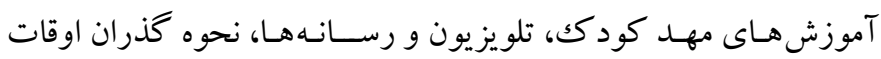

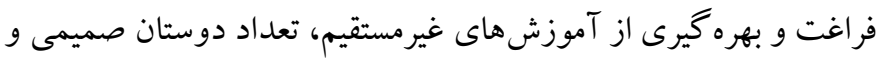

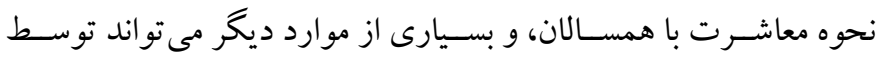

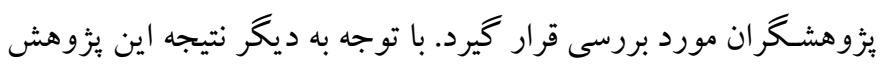

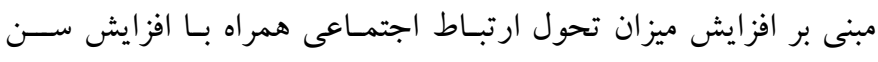

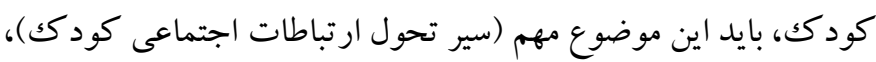

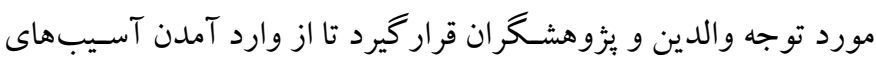
جدى به روند تحولى كودكى، جلو گيرى به عمل آيد.

تشكر و قدردانى: اين يُوهش، بر گرفته از رساله دكتراى آقاى مهدى قليجى

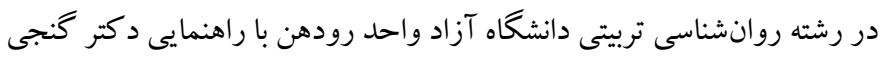

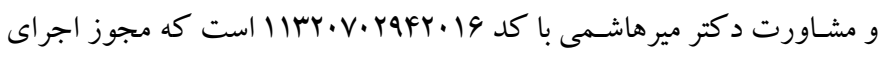

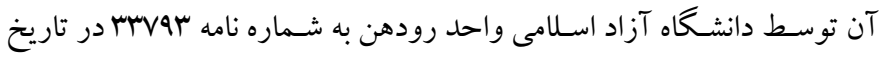

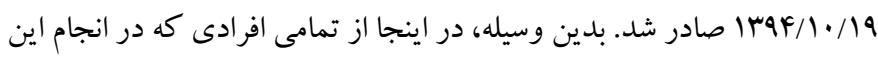
يروهش همكارى و مساعدت كردند، كمال تشكر را داريم. از مسئولان سازمان

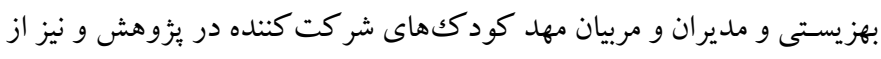

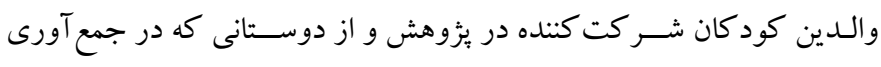

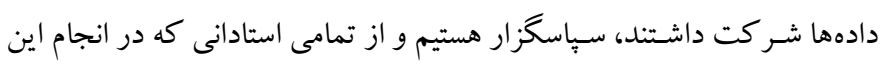

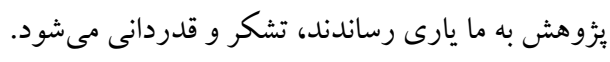

تضاد منافع: اين يثزوهش براى نويسند كان هيج گُونه تضاد منافعى نداشته

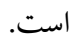

كودكك خواهد شـد (FY). كود كان در مهل كودك اين فرصت را بيدا

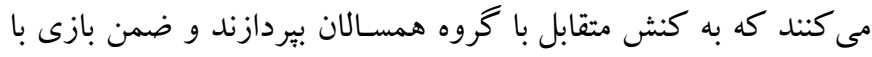

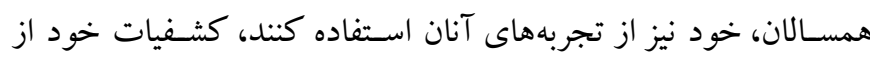

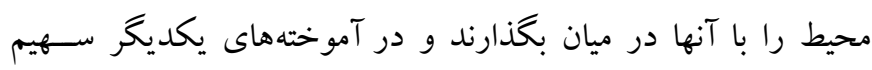

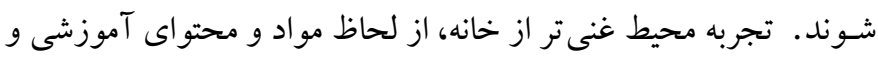

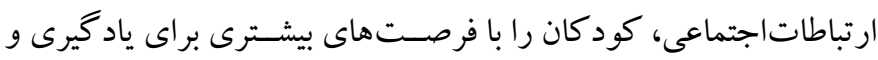

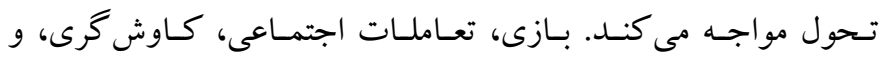

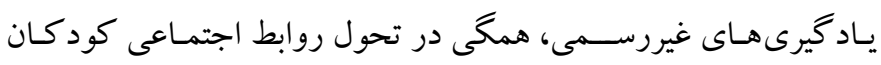

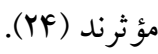

در مجموع نتـايج اين بثزوهش نشـــان دهنـده عـدم تـأثير متغيرهـاى جمعيتشـناختى خانو ادهها در روند روابط اجتماعى كود كان بوده است.

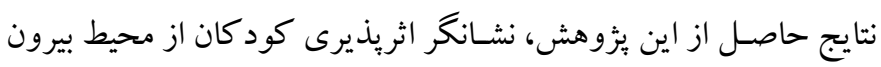

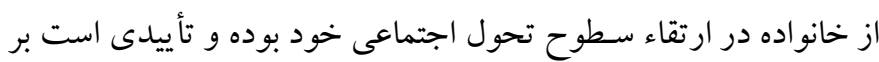

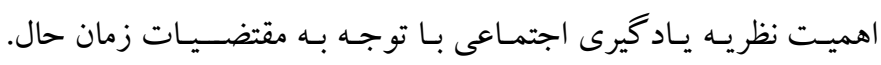

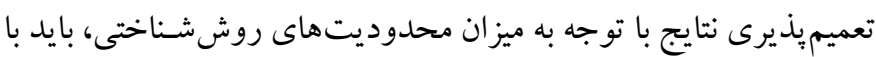

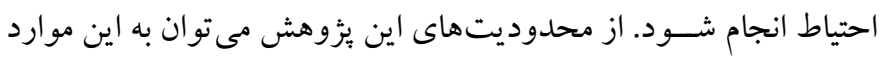

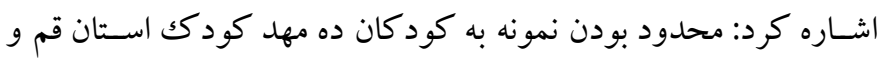

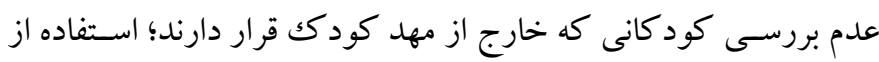

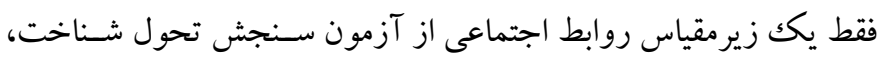

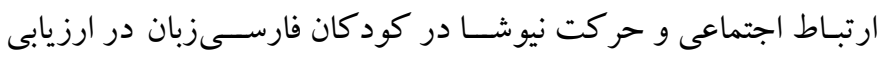
روابط اجتماعى كود كان؛ و محدود بودن حجم نمونه. بيشــهاد مى شــود

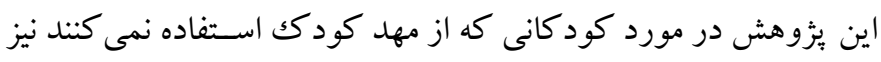

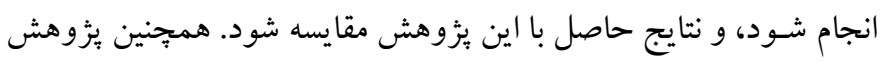

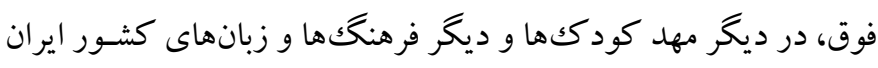




\section{References}

1. Diamond A, Lee K. Interventions shown to aid executive function development in children 4-12 years old. Science (New York, NY). 2011; 333(6045): 959-964. [Link]

2. Crozier S, Tincani MJ. Using a modified social story to decrease disruptive behavior of a child with autism. Focus Autism Other Dev Disabl. 2005; 20(3): 150157. [Link]

3. Rochat P. Early social cognition: Understanding others in the first months of life. Psychology Press; 2014, pp: 75-83. [Link]

4. Bellini S, Peters JK, Benner L, Hopf A. A metaanalysis of school-based social skills interventions for children with autism spectrum disorders. Remedial Spec Educ. 2007; 28(3): 153-162. [Link]

5. Abri S, Hajyousefi A, Hajbabayi H, Rahgozar M. Comparison of social development between 3-6 years old children who use rural child care center services and who don`t. Social Welfare Quarterly. 2011; 11(41): 343-368. [Persian]. [Link]

6. Behrendt HF, Scharke W, Herpertz-Dahlmann B, Konrad K, Firk C. Like mother, like child? Maternal determinants of children's early social-emotional development. Infant Ment Health J. 2019; 40(2): 234 247. [Link]

7. Vahedi S, Farrokhi F, Farajian F. Social competence and behavior problems in preschool children. Iran J Psychiatry. 2012; 7(3): 126-134. [Link]

8. Yasami S, Kian M, Geramipour M. Comparing social skills of 4 to 5 years old preschool children of EyvanE-Gharb city. Quarterly Preschool and Elementary School Studies. 2015; 1(2): 1-18. [Persian]. [Link]

9. Safari S, Hasanvand B, Fayyaz I, Bazargan S. An investigation into the influence of multidimensional curriculum-based preschool education on the development of social skills in preschool children. Educational Psychology. 2015; 11(37): 119-138. [Persian]. [Link]

10. Whiteside SPH, McCarthy DM, Sim LA, Biggs BK, Petrikin JE, Mellon MW. Development of the friendships and social skills test (FASST): A parent report measure. J Child Fam Stud. 2016; 25(6): 17771788. [Link]

11. Dadsetan P, Asgari A, Rahimzadeh S, Bayat M. Preschool children's social/emotional skills: A demographic comparison. Journal of Educational Psychology Studies. 2010; 7(11): 27-44. [Persian]. [Link]
12. Vikram K, Chen F, Desai S. Mothers' work patterns and children's cognitive achievement: Evidence from the India human development survey. Soc Sci Res. 2018; 72: 207-224. [Link]

13. Girard L-C, Pingault J-B, Doyle O, Falissard B, Tremblay RE. Expressive language and prosocial behaviour in early childhood: Longitudinal associations in the UK millennium cohort study. Eur J Dev Psychol. 2017; 14(4): 381-398. [Link]

14. Shams Esfand Abad H, Rowhany NS. The role of parent's personality traits in the social development of preschool children. Quarterly Journal of Child Mental Health. 2018; 4(4): 93-103. [Persian]. [Link]

15. Sahebi S, Arabi M, Velayati V. The effect of gymnastic exercises and free play on social skills and behavioral problems of children aged 3 to 6 years. Sport Psychology Studies. 2018; 7(25): 1-14. [Persian]. [Link]

16. Reynolds SA, Fernald LCH, Behrman JR. Mothers' labor market choices and child development outcomes in Chile. SSM - Population Health. 2017; 3: 756-766. [Link]

17. Delavar A. Theoretical and practical foundations of research in humanities and social sciences. Seventeen Edition. Tehran: Roshd; 2017, pp: 131-138. [Persian].

18. Jafari Z, Ashayeri H, Malayeri S, Alaedini F. Validity and reliability of Newsha cognitive, social communication and motor development scale in Persian speaking children. Iranian Journal of Psychiatry and Clinical Psychology. 2009; 15(1): 1824. [Persian]. [Link]

19. Maggi S, Irwin LG, Siddiqi A, Poureslami I, Hertzman E, Hertzman C. Knowledge network for early child development. Analytic and strategic review paper: International perspectives on early child development. 2005; pp: 6-9. [Link]

20. Yavarian R, Sohrabi F, Haghighi MM. Study of social - emotional skills development of children aged 1-4 years in Tehran kindergartens in 2013. Quarterly Journal of Child Mental Health. 2018; 5(1): 117-126. [Persian]. [Link]

21. Shalani B, Azadimanesh P. The comparison of efficacy of group art therapy and puppet play therapy on the social skills of children with attention deficit/ hyperactivity disorder. Quarterly Journal of Child Mental Health. 2016; 2(4): 103-112. [Persian]. [Link]

22. Barzegar Bafrooei K, Amogadiri M. The impact of playing with Lego on social skills of preschool children. Quarterly Journal of Child Mental Health. 2017; 4(3): 130-142. [Persian]. [Link] 
23. Vahedi M, Bigdeli Z. Effectiveness of organized games on the level of learning and intelligence of preschoolers. Counseling Culture and Psycotherapy. 2018; 9(33): 187-206. [Persian]. [Link]

24. Movahedzadeh B, Safaei-Ardakani R. Comparing social development, cognitive-motor development and behavioral problems of first grade female students in primary school with and without kindergarten service. SALAMAT IJTIMAI (Community Health). 2018; 5(1): 48-56. [Persian]. [Link]

25. Saracostti M, Lara L, Martella D, Miranda H, Miranda-Zapata ED, Reininger T. Influence of family involvement and children's socioemotional development on the learning outcomes of Chilean students. Front Psychol. 2019; 10: 335. [Link]

26. Aflatoonian B, Alam M, Mohamadi Purnajib T, Mohamadzadeh M. Evaluation and comparison of behavior problems of 7 to 9 years old children based on working mothers and housewives in Kerman. Journal of Health \& Development. 2014; 3(2): 94-104. [Persian]. [Link]

27. Tong L, Shinohara R, Sugisawa Y, Tanaka E, Maruyama A, Sawada Y, et al. Relationship of working mothers' parenting style and consistency to early childhood development: A longitudinal investigation. J Adv Nurs. 2009; 65(10): 2067-2076. [Link]
28. Hill JL, Waldfogel J, Brooks-Gunn J, Han W-J. Maternal employment and child development: A fresh look using newer methods. Dev Psychol. 2005; 41(6): 833-850. [Link]

29. Liu H, Mroz TA, van der Klaauw W. Maternal employment, migration, and child development. J Econom. 2010; 156(1): 212-228. [Link]

30. Ruhi A, Behnām A. A study on the impact of preschool education on the development of Persian oral skills of Azari 1st grade students. Educational Innovations. 2011; 10(3): 25-50. [Persian]. [Link]

31. Tremblay RE, Nagin DS, Séguin JR, Zoccolillo M, Zelazo PD, Boivin M, et al. Physical aggression during early childhood: Trajectories and predictors. Pediatrics. 2004; 114(1): e43-50. [Link]

32. Rentzou K. Prevalence of burnout syndrome of Greek child care workers and kindergarten teachers. Educ 3 13. 2015; 43(3): 249-262. [Link]

33. Day DV, Fleenor JW, Atwater LE, Sturm RE, McKee RA. Advances in leader and leadership development: A review of 25years of research and theory. Leadersh Q. 2014; 25(1): 63-82. [Link]

34. Soleimany Adriany S, Sadeghi Hosnije AH, Zerehpoush A, Rabie M, Abedi A, Esmaeeli S. Effectiveness of rhythmic games on social skills of children with attention deficit hyperactive disorder. Journal of Gorgan University of Medical Sciences. 2016; 18(2): 91-96. [Persian]. [Link] 